\title{
Anacardium excelsum phytochemical analysis and in vitro antimicrobial activity against oral cavity microorganisms
}

\author{
Andrés M. Rojas', Clara J. Durango', Solanlly E. García³, Diego Castañeda-Peláez²,3, \\ Dabeiba A. García², Fredy Gamboa 2,4
}

1. Universidad Antonio Nariño, Facultad de Ciencias, Armenia - Quindío, Colombia.

2. Pontificia Universidad Javeriana, Facultad de Odontología, Centro de Investigaciones Odontológicas, Bogotá, Colombia.

3. Universidad Antonio Nariño, Facultad de Odontología, Armenia - Quindío, Colombia

4. Pontificia Universidad Javeriana, Facultad de Ciencias, Departamento de Microbiología, Bogotá, Colombia

\begin{abstract}
Infections of the oral cavity have a broad microbial etiological profile that varies according to each microenvironment in the mouth. Such infections often require antimicrobial treatment, which can lead to the development of resistance. There is thus a need to find new therapeutic strategies based on natural plant-derived compounds. The aim of this study was to determine the phytochemical nuclei and the antimicrobial effect of Anacardium excelsum leaf and stem extracts, and of fractions derived from the leaf extract, against Streptococcus mutans ATCC 25175, Staphylococcus aureus ATCC 35548, Escherichia coli ATCC 25922, Enterococcus faecalis ATCC 19433 and Candida albicans ATCC 10231. The plant material was collected from the Quindio Botanical Garden (Calarcá, Quindio-Colombia), located at an altitude of 1500 meters above sea level. Hydroalcoholic extracts of $\mathrm{A}$. excelsum leaves and stems, and fractions of the hydroalcoholic leaf extract, were obtained by percolation extraction. Phytochemical nuclei were identified by thin layer chromatography. The antimicrobial activity of the extracts and fractions (at concentrations of 2, $5,10,20$ and $40 \mathrm{mg} / \mathrm{ml}$ ) against the five ATCC reference
\end{abstract}

strains was evaluated using the well diffusion technique on Mueller-Hinton agar. The leaf extract showed no antimicrobial activity against $\mathrm{E}$. coli, but it did show antimicrobial activity against S. mutans, S. aureus, E. faecalis and C. albicans, at a concentration of $10 \mathrm{mg} / \mathrm{ml}$, with zones of inhibition of 9 to $11 \mathrm{~mm}$. The ethyl acetate and acetone fractions obtained from A. excelsum leaf extract had greatest antimicrobial activity at $10 \mathrm{mg} / \mathrm{ml}$. In conclusion, (1) the A. excelsum leaf extract, and the ethyl acetate and acetone fractions obtained from the leaf extract, had the greatest antimicrobial activity on all the study microorganisms, and (2) the phytochemical nuclei in the fractions (ethyl acetate and acetone) were found to contain phenolic-type compounds, tannins, triterpene-type terpenes and steroidal-type terpenes, which might explain the antimicrobial activity observed..

Received: January 2021; Accepted: May 2021.

Keywords: anacardium - plant bioactive compound - antiinfective agent - oral cavity.

\section{Análisis fitoquímico y actividad antimicrobiana in vitro de Anacardium excelsum sobre microorganismos de cavidad bucal}

\begin{abstract}
RESUMEN
Las infecciones de la cavidad bucal se caracterizan por presentar un amplio perfil etiológico microbiano que varía de acuerdo a cada microambiente en boca. En muchos casos estas infecciones requieren tratamiento antimicrobiano que puede conducir al desarrollo de resistencia. Estos hechos en conjunto generan la necesidad de buscar nuevas estrategias terapéuticas, provenientes de compuestos naturales derivados de plantas. El objetivo de este estudio fue determinar los núcleos fitoquímicos y el efecto antimicrobiano de extractos de hojas y tallos, y de fracciones derivadas del extracto de hojas de Anacardium excelsum contra Streptococcus mutans ATCC 25175, Staphylococcus aureus ATCC 35548, Escherichia coli ATCC 25922, Enterococcus faecalis ATCC 19433 y Candida albicans ATCC 10231. El material vegetal se colectó del Jardín Botánico del Quindio (Calarcá, Quindio-Colombia), situado
\end{abstract}

a una altura de 1500 msnm. Se obtuvieron extractos hidroalcohólicos de hojas y tallos, y fracciones a partir del extracto hidroalcohólico de hojas de A. excelsum mediante extracción por percolación. La identificación de los núcleos fitoquímicos fue realizado por cromatografía en capa delgada. La evaluación de la actividad antimicrobiana de extractos y fracciones, en concentraciones de 2, 5, 10, 20 y $40 \mathrm{mg} / \mathrm{ml}$, frente a las 5 cepas de referencia ATCC, se realizó mediante la técnica de difusión con aplicación en pozo sobre agar Mueller-Hinton. El extracto de hojas no presentó actividad antimicrobiana sobre E. coli pero si sobre $S$. mutans, S. aureus, E. faecalis y C. albicans, en una concentración de $10 \mathrm{mg} / \mathrm{ml}$, con halos de inhibición desde 9 a $11 \mathrm{~mm}$, y las fracciones de acetato de etilo y acetona obtenidas del extracto de hojas de A. excelsum, presentaron mayor actividad antimicrobiana en una concentración de 10 
$\mathrm{mg} / \mathrm{ml}$. En conclusión, 1. El extracto de hojas y las fracciones de acetato de etilo y acetona obtenidas del extracto de hojas de A. excelsum presentaron mayor actividad antimicrobiana sobre todos los microorganismos en estudio; 2. La evaluación de los núcleos fitoquímicos en las fracciones acetato de etilo $y$ de acetona mostraron compuestos de tipo fenólico, taninos,

\section{INTRODUCTION}

Infections of the oral cavity have a broad microbial etiological profile, which varies according to the specific ecosystem in each part of the mouth, causing a range of clinical pictures with differing frequencies and seriousness ${ }^{1,2}$. Among these infections, odontogenic infections alone account for $7 \%$ to $10 \%$ of the total antibiotic therapy used in populations, with some cases requiring a combination of treatments and medications for resolution. Moreover, several studies have shown that oral infections can be a risk factor leading to the onset, development and progression of systemic diseases $^{3}$. All of this, added to the problem of the increasing bacterial resistance to antimicrobial agents, creates a pressing need to find new antimicrobial strategies ${ }^{4}$.

Within the microbial etiology of infections of the oral cavity, the pathogenic flora consists mainly of Streptococcus and Staphylococcus species, as well as a series of opportunistic microorganisms ${ }^{2}$. Streptococcus mutans has often been associated to the onset and progression of dental caries -a disease with high repercussion in the oral cavityas well as other infections of odontogenic origin ${ }^{5}$. Staphylococcus aureus is present in abscesses of odontogenic origin, being the second most important microorganism following the viridans group of Streptococci, and appearing recurrently in different infectious lesions of the oral cavity ${ }^{6}$. Escherichia coli, which is a very important microorganism of the family Enterobacteriaceae, is also often found in infections of the oral cavity and has great capacity to develop resistance to antimicrobial agents? Enterococcus faecalis is associated to root canal infections, as well as being recognized for its broad resistance to different antimicrobial agents ${ }^{8}$. Finally, Candida albicans is an opportunistic fungus, and due to its long persistence time in the tissues that it infects, it is closely associated to denture-related stomatitis and different types of candidiasis which are difficult to treat ${ }^{9}$. terpenos del tipo triterpenos y terpenos del tipo esteroidal, que posiblemente expliquen la actividad antimicrobiana obtenida.

Palabras clave: anacardium - compuestos bioactivos de plantas - agentes anti-infecciosos, cavidad bucal.

The particular behavior of many microbial species involved in infections of the oral cavity, and the difficulty to treat some of them, have led to increasing interest in the search for and development of new natural plant-based antimicrobial agents ${ }^{10-}$ ${ }^{12}$ Around the world, many different plant species have been used as sources of natural medicines for the treatment of diseases ${ }^{10-12}$. In vitro studies have found some raw extracts from plant species to be potentially useful in controlling multidrug resistance ${ }^{13}$. The plant Anacardium excelsum (family Anacardiaceae), known in the Andean region by the common name Caracoli, has promising potential for antimicrobial activity. It is a gigantic tree that grows along rivers in tropical zones of the Americas below $1300 \mathrm{~m}$ above sea level. Its wood is used commercially for carpentry and canoe building ${ }^{14}$. Within the Anacardium family, Anacardium occidentale L. and Anadenanthera macrocarpa are known to have anticariogenic activity ${ }^{15}$, while Anacardium occidentale $L^{16}$ and Anacardium microcarpum ${ }^{17}$ are known to have antibacterial activity on chemoresistant strains of $S$. aureus. In 2011, Celis et al. ${ }^{18}$ reported the antimicrobial activity of extracts and fractions from the species Anacardium excelsum against Bacillus subtillis and Staphylococcus aureus, suggesting that such extracts and fractions may have a potential role in controlling progression and development of dental caries and other odontogenic infections. However, the microbial action of $A$. excelsum extracts has not yet been explored against the microbial pathogens S. mutans, S. aureus, E. coli, E. faecalis and $C$. albicans, despite their importance as the cause of a range of infections of the oral cavity.

The aim of this study was to determine the phytochemical nuclei and the antimicrobial effect of Anacardium excelsum leaf and stem extracts, and of fractions derived from the leaf extract, against reference ATCC strains of $S$. mutans, $S$. aureus, $E$. coli, E. faecalis and C. albicans. 


\section{MATERIALS AND METHODS \\ Collection of plant material}

Anacardium excelsum was collected from the Quindío

Botanical Garden, located in the municipality of Calarcá-Quindío (Colombia) at an elevation of $1500 \mathrm{~m}$ above sea level. The plant species was characterized by a botanical expert, who collected and classified the material. For authentication of the plant material collected, a specimen was sent to the herbarium at the University of Quindío, where it was identified as Anacardium excelsum.

\section{Extraction}

Anacardium excelsum leaves and stems were processed in the laboratory of the School of Basic Sciences at the Antonio Nariño University, Armenia site (Colombia). Approximately $3000 \mathrm{~g}$ of each dried plant material was weighed at ambient temperature and ground in a hammer mill. Then it was macerated at ambient temperature in ethanol:water $(7: 3)$, for 15 days. The solvent mixture was retrieved for recirculation using a low-pressure rotary evaporator. The extracts were weighed, their yield percentage calculated, and finally labeled and stored at ambient temperature.

\section{Fractionation}

Fractionation of the hydroalcoholic extract of $A$. excelsum leaves only was performed with extraction by percolation. To do so, $150 \mathrm{~g}$ of the hydroalcoholic extract of $A$. excelsum leaves was weighed and resuspended in the (7:3) ethanol:water system until a homogenous solution was obtained. This extract was absorbed on silica gel flash 100G (Millipore ${ }^{\mathbf{T M}}$, Merck KGaA - Darmstadt, Germany) until a fine powder was obtained. For fractionation of the extract, silica 60G (Millipore ${ }^{\mathbf{T M}}$, Merck KGaA Darmstadt, Germany) was used as an extraction base, and solvents with different polarities were used, beginning with the lowest polarity and moving to the highest (ethyl acetate, acetone, ethanol and water). The fractions were dried in a low pressure rotary evaporator. Their yields were calculated and then they were labeled and stored at ambient temperature. Finally, the extracts and fractions were eluted in different solvent systems using thin-layer chromatography (TLC), for which they were resuspended in the appropriate solvents. The phytochemical nuclei present in these fractions of A. excelsum leaves were identified using thin layer chromatography and spraying the plate with specific reagents to identify the most relevant nuclei.

\section{Chromatography}

Primary fractionation of the hydroalcoholic extract of $A$. excelsum leaves was followed by thin layer chromatography using as stationary phase $1 \mathrm{~mm}$ thick TLC plates with silica gel $60 \mathrm{~F}_{254}$ (Millipore $^{\mathbf{T M}}$, Merck KGaA - Darmstadt, Germany) on aluminum. Elution was performed with a solvent system at different polarities. The plates were developed using $254 \mathrm{~nm}$ short-wave and $365 \mathrm{~nm}$ long-wave light. The phytochemical nuclei were identified by thin layer spray with specific reagents for alkaloids, flavonoids, terpenes, phenols and coumarins (Table 1).

\section{Evaluation of the antimicrobial activity of} extracts and fractions. Study strains

The $A$. excelsum leaf and stem extracts, and the fractions from the hydroalcoholic leaf extract were evaluated on the reference strains Streptococcus mutans ATCC 25175, Staphylococcus aureus ATCC 35548, Escherichia coli ATCC 25922, Enterococcus faecalis ATCC 19433 and Candida albicans ATCC 10231. These were lyophilized strains, preserved by freezing at $-70^{\circ} \mathrm{C}$ at the Microbiology Laboratory of the Center for Dental Research of the Pontificia Universidad Javeriana. The microorganisms were reconstituted and made viable in $5 \mathrm{~mL}$ of brain heart infusion (BHI) broth and incubated for 24 hours at $37{ }^{\circ} \mathrm{C}$ under anaerobic conditions $\left(\mathrm{H}_{2}: \mathrm{CO}_{2}: \mathrm{N}_{2}\right.$ 10:10:80). Then, for isolation and viability and purity testing, they were plated on BHI agar (BrainHeart Infusion Agar) and incubated for 1-3 days at $37{ }^{\circ} \mathrm{C}$ under anaerobic conditions $\left(\mathrm{H}_{2}: \mathrm{CO}_{2}: \mathrm{N}_{2}\right.$ 10:10:80). Finally, the colonies grown on $\mathrm{BHI}$ agar were reconfirmed using Gram stain and biochemical tests.

\section{Well-diffusion method}

Antibacterial activity was identified using the agar well diffusion method on Mueller-Hinton agar, as described in Dobner et al. ${ }^{19}$. Suspensions of each fresh, viable bacterial strain were prepared in isotonic saline solution and adjusted to 0.5 on the McFarland scale. Each bacterial suspension was immediately swabbed on Mueller-Hinton agar, following the Kirby-Bauer technique ${ }^{20}$. After plating all the bacteria on Mueller-Hinton Agar, a $0.5 \mathrm{~cm}$ Pasteur pipette was used to make wells (distributed 
Table 1. Phytochemical nuclei studied in extracts and fractions obtained from Anacardium excelsum.

\begin{tabular}{|c|c|c|c|}
\hline \multicolumn{2}{|c|}{ Phytochemical nuclei } & Positive standard & Chemical developer \\
\hline \multicolumn{2}{|c|}{ Alkaloids } & Caffeine and Quinine & Dragendorff \\
\hline \multicolumn{2}{|c|}{ Flavonoids } & Rutin & $\mathrm{Pb}\left(\mathrm{C}_{2} \mathrm{H}_{3} \mathrm{O}_{2}\right)_{2} 25 \%$ \\
\hline \multirow{2}{*}{ Terpenes } & Triterpenes & Turpentine & Vanillin $-\mathrm{H}_{3} \mathrm{PO}_{4}\left(\mathrm{H}_{3} \mathrm{PO}_{4}\right)$ \\
\hline & Steroids & Cholesterol & $\mathrm{SbCl}_{3} / \mathrm{CHCl}_{3}$ y $\mathrm{CH}_{3} \mathrm{COOH}$ \\
\hline \multicolumn{2}{|c|}{ Phenols and Tannins } & Catechol (phenol) & $\mathrm{FeCl}_{3} 5 \%$ in $\mathrm{HCl} 0.5 \mathrm{~N}-\left(\mathrm{FeCl}_{3}\right)$ \\
\hline \multicolumn{2}{|c|}{$\begin{array}{l}\text { Coumarins } \\
\text { (ortho-hydroxy) }\end{array}$} & & Benedict \\
\hline
\end{tabular}

evenly on the agar). Then, $30 \mu \mathrm{L}$ of the extracts, fractions, and positive and negative controls were placed in their corresponding wells. For each fraction (ethyl acetate, acetone, ethanol and water), concentrations of $2,5,10,20$ and $40 \mathrm{mg} / \mathrm{ml}$ were evaluated to determine the lowest concentration that inhibits bacterial growth. Negative control was $1 \%$ dimethyl sulfoxide (DMSO) and positive controls were $150 \mathrm{ug} / \mathrm{ml}$ vancomycin and $0.12 \%$ chlorhexidine. All tests were performed in duplicate and incubated at $37{ }^{\circ} \mathrm{C}$ for $24-48$ hours. Following the incubation period, the diameters of the zones of inhibition were measured in millimeters and the two values averaged.

\section{RESULTS}

\section{Chromatographic analysis}

Table 2 shows the phytochemical nuclei studied in the fractions obtained from the hydroalcoholic extract of Anacardium excelsum leaves. Of the phytochemical nuclei studied, in the ethyl acetate (Fig. 1) and acetone fractions, only presence of phenols and tannins, as well as triterpene-type terpenes and steroidal terpenes, was identified. For the ethanol fraction, evaluation showed the presence of phenolic-type compounds and absence of alkaloids, flavonoids, terpenes and coumarins. In the fraction with highest polarity (aqueous), only presence of alkaloids, phenolic-type compounds, tannins and triterpene-type terpenes was found. Coumarins and flavonoid-type compounds were not found in any of the four fractions studied.

\section{Antimicrobial activity of extracts}

Table 3, parts A and B, show the antimicrobial activity of the A. excelsum extracts and fractions on the five microorganisms used in the study. Leaf extract had antimicrobial activity on $S$. mutans, $S$. aureus, $E$. faecalis and C. albicans, from concentrations of 10 $\mathrm{mg} / \mathrm{mL}$ to $40 \mathrm{mg} / \mathrm{ml}$, with zones of inhibition of 9 to $11 \mathrm{~mm}$. None of the leaf extract concentrations evaluated inhibited $E$. coli. None of the stem extract concentrations evaluated inhibited $S$. mutans, E. coli or $C$. albicans, though they did inhibit $E$. faecalis at concentrations of $10 \mathrm{mg} / \mathrm{mL}$ to $40 \mathrm{mg} / \mathrm{ml}$, with zones of inhibition of $11 \mathrm{~mm}$; and $S$. aureus only at $40 \mathrm{mg} / \mathrm{mL}$, with a zone of inhibition of $10 \mathrm{~mm}$.

\section{Antimicrobial activity of leaf extract fractions}

Based on its antimicrobial activity on these bacteria, the leaf extract was fractionated and the antimicrobial activity of the resulting fractions assessed. The fractions with greatest inhibitory activity were ethyl acetate and acetone, which inhibited all study microorganisms as from concentrations of $10 \mathrm{mg} /$ $\mathrm{ml}$ with zones of inhibition ranging from 9 to 20 $\mathrm{mm}$ (Table 3 and Fig. 2). The ethyl acetate fraction inhibited all microorganisms at concentrations of 10,20 and $40 \mathrm{mg} / \mathrm{ml}$ with zones of inhibition of 9 to $15 \mathrm{~mm}$. The acetone fraction inhibited $S$. mutans, E. faecalis and C. albicans at concentrations of 10, 20 and $40 \mathrm{mg} / \mathrm{ml}$ with zones of inhibition of 10 to $14 \mathrm{~mm}$, and inhibited $S$. aureus and $E$. coli only at concentrations of 20 and $40 \mathrm{mg} / \mathrm{ml}$, with zones of inhibition of 9 to $20 \mathrm{~mm}$. In general, the other two fractions (ethanol and aqueous) showed less activity on the 5 microorganisms evaluated. Table 3 also shows the inhibition results produced by the positive controls (chlorhexidine $0.12 \%$ and vancomycin 150 $\mathrm{ug} / \mathrm{ml}$ ) and negative control (DMSO 1\%).

\section{DISCUSSION}

Due to its wide range of plant biodiversity, and favored by its geographic location, Colombia holds great promise for the discovery and development of new substances with pharmacological potential ${ }^{10}$. It is well known that secondary metabolites derived from plant species have shown therapeutic 


\begin{tabular}{|c|c|c|c|c|c|}
\hline \multirow{2}{*}{\multicolumn{2}{|c|}{ Phytochemical nuclei and developing reagent }} & \multicolumn{4}{|c|}{ Fractions } \\
\hline & & Ethyl Acetate & Acetone & Ethanol & Water \\
\hline \multicolumn{2}{|c|}{ Alkaloids (Dragendorff) } & Negative & Negative & Negative & Positive \\
\hline \multicolumn{2}{|c|}{ Flavonoids (Lead Acetate 25\%) } & Negative & Negative & Negative & Negative \\
\hline \multirow[b]{2}{*}{ Terpenes } & Triterpenes (Vanillin - H3PO4) & Positive & Positive & Negative & Positive \\
\hline & $\begin{array}{l}\text { Steroids (SbCl3/Chloroform and } \\
\text { acetic acid) }\end{array}$ & Positive & Positive & Negative & Negative \\
\hline \multicolumn{2}{|c|}{$\begin{array}{l}\text { Phenols and Tannins (5\% Iron (III) chloride in } \mathrm{HCl} \\
\qquad 0.5 \mathrm{~N}-\mathrm{FeCl} 3)\end{array}$} & Positive & Positive & Positive & Positive \\
\hline \multicolumn{2}{|c|}{$\begin{array}{l}\text { Coumarins } \\
\text { (ortho-hydroxy) (Benedict) }\end{array}$} & Negative & Negative & Negative & Negative \\
\hline
\end{tabular}

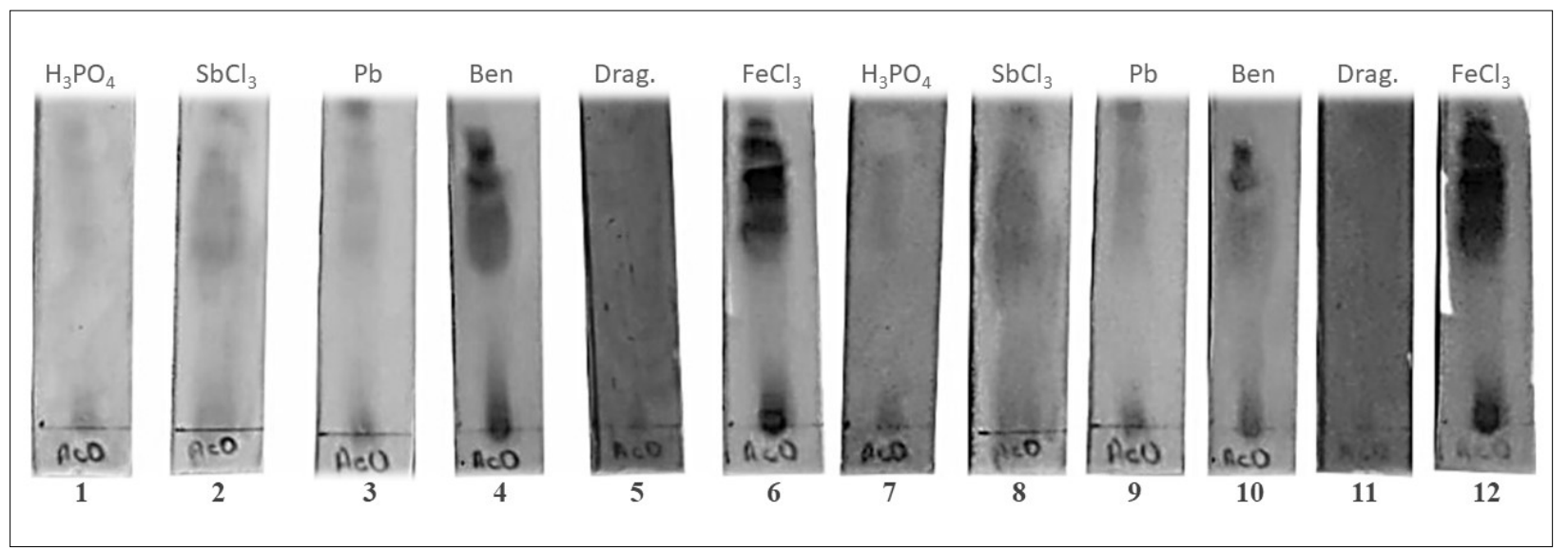

Fig. 1: Results obtained for phytochemical nuclei on TLC plates for the ethyl acetate fraction. Plates 1 to 6 (developed with UV light at $254 \mathrm{~nm}$ ) and plates 7 to 12 (observed with specific developers). Presence of triterpene-type terpene nuclei (plates 1 and 7), steroidal terpenes (plates 2 and 8) and phenolic compounds (plates 6 and 12), and absence of coumarins (plates 4 and 10), flavonoids (plates 3 and 9) and alkaloids (plates 5 and 11).

action against various diseases ${ }^{21}$. Thus, different plant species have been studied to determine the presence of substances with pharmacological activity, including, among others, Berberis goudotii, Isertia laevis, Borrichia frutences, Sarcocephalus coadunatus, Elaeagia utilis and Stevia rebaudiana, with the aim of broadening the antimicrobial arsenal used to treat diseases of interest to public health, such as infectious diseases of the oral cavity ${ }^{11,12,22,23}$. The current study evaluated the antimicrobial activity of hydroalcoholic extracts of leaves and stems, as well as fractions derived from the leaf extract, of the plant species Anacardium excelsum, which is endemic to Colombia. Celis et al. ${ }^{18}$ conducted in vitro studies which showed that $A$. excelsum extracts inhibited the growth of Gram-positive bacteria such as Staphylococcus aureus and Bacillus subtillis, but showed no activity against Gram-negative bacteria such as Escherichia coli and Salmonella ${ }^{18}$.
The results of the current study clearly showed that of the two extracts evaluated, leaf extract had more antimicrobial activity on the microorganisms evaluated at concentrations of 10,20 and $40 \mathrm{mg} /$ $\mathrm{ml}$. For this reason, the leaf extract was fractionated using four solvents (ethyl acetate, acetone, ethanol and water) and concentrations of $2 \mathrm{mg} / \mathrm{ml}, 5 \mathrm{mg} /$ $\mathrm{ml}, 10 \mathrm{mg} / \mathrm{ml}, 20 \mathrm{mg} / \mathrm{ml}$ and $40 \mathrm{mg} / \mathrm{ml}$. The ethyl acetate fraction had the greatest antimicrobial activity, followed by the acetone fraction and, to a lesser degree, the ethanol and water fractions. The ethyl acetate and acetone fractions had antimicrobial activity at concentrations of 10,20 and $40 \mathrm{mg} / \mathrm{ml}$. Outstanding was the high inhibition of the ethyl acetate fraction at concentrations of 10, 20 and 40 $\mathrm{mg} / \mathrm{ml}$ on C. albicans, E. faecalis and S. aureus with zones of inhibition of 13.5 to $15 \mathrm{~mm}$, and lower inhibition on $S$. mutans and $E$. coli, with zones of inhibition of $9 \mathrm{~mm}$ to $11 \mathrm{~mm}$. In general, the 
Table 3. Part A. Antimicrobial activity of $A$. excelsum leaf and stem hydroalcoholic extracts and fractions derived from the hydroalcoholic extract of leaves against S. mutans ATCC 25175, S. aureus ATCC 35548 and E. coli ATCC 25922. Zones of inhibition expressed in $\mathrm{mm}$ for averages of duplicate tests.

\begin{tabular}{|c|c|c|c|c|c|c|c|c|c|c|c|c|c|c|c|}
\hline \multirow{2}{*}{$\begin{array}{l}\text { Microorganism } \\
\text { Concentrations of the } \\
\text { product in } \mathrm{mg} / \mathrm{ml}\end{array}$} & \multicolumn{5}{|c|}{$\begin{array}{c}\text { S. mutans } \\
\text { ATCC } 25175\end{array}$} & \multicolumn{5}{|c|}{$\begin{array}{c}\text { S. aureus } \\
\text { ATCC } 35548\end{array}$} & \multicolumn{5}{|c|}{$\begin{array}{c}\text { E. coli } \\
\text { ATCC } 25922\end{array}$} \\
\hline & 2 & 5 & 10 & 20 & 40 & 2 & 5 & 10 & 20 & 40 & 2 & 5 & 10 & 20 & 40 \\
\hline Leaf extract & 0 & 0 & 9 & 9.5 & 9.5 & 0 & 0 & 9 & 9 & 11 & 0 & 0 & 0 & 0 & 0 \\
\hline Stem extract & 0 & 0 & 0 & 0 & 0 & 0 & 0 & 0 & 0 & 10 & 0 & 0 & 0 & 0 & 0 \\
\hline Ethyl acetate fraction & 0 & 0 & 9 & 10 & 11 & 0 & 0 & 13.5 & 13.5 & 15 & 0 & 0 & 9 & 9 & 9 \\
\hline Acetone fraction & 0 & 0 & 10 & 10 & 10 & 0 & 0 & 0 & 20 & 10 & 0 & 0 & 0 & 9 & 10 \\
\hline Ethanol fraction & 0 & 0 & 0 & 0 & 0 & 0 & 0 & 0 & 9 & 10 & 0 & 0 & 0 & 0 & 0 \\
\hline Water fraction & 0 & 0 & 0 & 0 & 0 & 0 & 0 & 0 & 9 & 10 & 0 & 0 & 0 & 0 & 9 \\
\hline $\begin{array}{l}\text { Positive control: } \\
\text { Chlorhexidine } 0.12 \%\end{array}$ & 19 & 19 & 19 & 19 & 19 & 18 & 18 & 18 & 18 & 18 & 18.8 & 18.8 & 18.8 & 18.8 & 18.8 \\
\hline $\begin{array}{l}\text { Positive control: } \\
\text { Vancomycin ( } 150 \mathrm{ug} / \\
\mathrm{ml} \text { ) }\end{array}$ & 17.8 & 17.8 & 18 & 18 & 18 & 18 & 18 & 18 & 18 & 18 & 0 & 0 & 0 & 0 & 0 \\
\hline $\begin{array}{l}\text { Negative control: } \\
\text { DMSO } 1 \%\end{array}$ & 0 & 0 & 0 & 0 & 0 & 0 & 0 & 0 & 0 & 0 & 0 & 0 & 0 & 0 & 0 \\
\hline
\end{tabular}

Table 3. Part B. Antimicrobial activity of $A$. excelsum leaf and stem hydroalcoholic extracts and fractions derived from the hydroalcoholic extract of leaves against $E$. faecalis ATCC 19433, and C. albicans ATCC 10231. Zones of inhibition expressed in $\mathrm{mm}$ for averages of duplicate tests.

\begin{tabular}{|c|c|c|c|c|c|c|c|c|c|c|}
\hline \multirow{2}{*}{$\begin{array}{l}\text { Microorganism } \\
\text { Concentrations of the product in } \mathrm{mg} / \mathrm{ml}\end{array}$} & \multicolumn{5}{|c|}{$\begin{array}{c}\text { E. faecalis } \\
\text { ATCC } 19433\end{array}$} & \multicolumn{5}{|c|}{$\begin{array}{l}\text { C. albicans } \\
\text { ATCC } 10231\end{array}$} \\
\hline & 2 & 5 & 10 & 20 & 40 & 2 & 5 & 10 & 20 & 40 \\
\hline Leaf extract & 0 & 0 & 10 & 10 & 10 & 0 & 0 & 10 & 10 & 11 \\
\hline Stem extract & 0 & 0 & 11 & 11 & 11 & 0 & 0 & 0 & 0 & 0 \\
\hline Ethyl acetate fraction & 0 & 0 & 14 & 14 & 14 & 0 & 0 & 14.5 & 15 & 15 \\
\hline Acetone fraction & 0 & 0 & 9 & 11 & 11 & 0 & 0 & 10 & 11 & 14 \\
\hline Ethanol fraction & 0 & 0 & 9 & 11 & 11 & 0 & 0 & 0 & 9 & 10 \\
\hline Water fraction & 0 & 0 & 9 & 10 & 10 & 0 & 0 & 0 & 9 & 10 \\
\hline Positive control: Chlorhexidine $0.12 \%$ & 16.5 & 16.5 & 16.5 & 16.5 & 16.5 & 20 & 20 & 20 & 20 & 20 \\
\hline Positive control: Vancomycin (150 ug/ml) & 19.3 & 19.3 & 19.3 & 19.3 & 19.3 & 0 & 0 & 0 & 0 & 0 \\
\hline Negative control: DMSO 1\% & 0 & 0 & 0 & 0 & 0 & 0 & 0 & 0 & 0 & 0 \\
\hline
\end{tabular}

microorganism least inhibited by the 4 fractions was E. coli, in agreement with Celis et al. ${ }^{18}$.

In the current study, the two most active fractions (ethyl acetate and acetone) obtained from $A$. excelsum leaves behaved chemically in the same way, with compounds only of phenolic type, tannins, triterpene-type terpenes and steroidal-type terpenes. Celis et al. ${ }^{18}$ suggest that the antimicrobial activity of these two fractions against the study microorganisms was due to the presence of these phytochemical nuclei. Celis et. al ${ }^{18}$ identified that the compounds 2- (1,1-dimethylethyl) -4- (1,1,3,3-tetramethylbutyl) phenol and 2,2'-methylenebis (6- (1,1-dimethylethyl) -4-ethylphenol, characterized by gas chromatographymass spectrometry (GC/MSD), present in mediumpolarity fractions of $A$. excelsum, had powerful antimicrobial and antiseptic properties, and thus, excellent antimicrobial activity due to their biological potential ${ }^{18}$.

The current study found presence of terpenes and phenols in the ethyl-acetate and acetone fractions. 


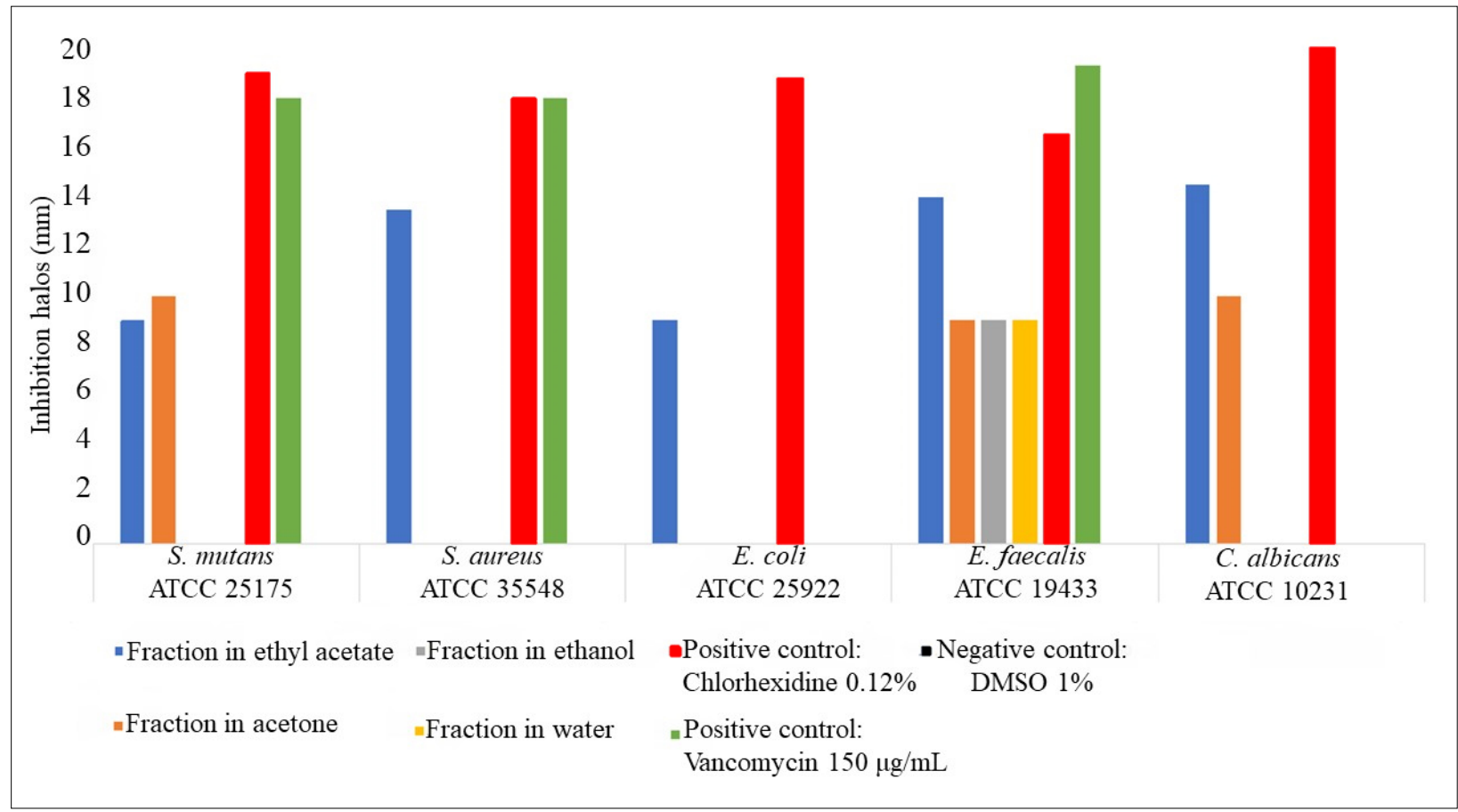

Fig. 2: Antimicrobial action of the fractions of A. excelsum leaf hydroalcoholic extracts at concentration of $10 \mathrm{mg} / \mathrm{mL}$ on the 5 study microorganisms.

Other studies have found that terpenes are important components that produce antimicrobial activity in species of the family Rubiaceae, and that phenols and phenolic acids are the main components in plants with antimicrobial activity ${ }^{24,25}$.

Urrea et al. $^{14}$ assessed the antibacterial activity of extracts from $A$. excelsum, and using gas chromatography, identified the compounds oleic acid, octadecanoic acid; 9-octadecenoic acid; 2-methyl-3(Z), 13(Z)-octadecadienol; 2-hydroxy-1(hydroxymethyl)ethyl-9(Z), 12(Z)-octadecadienoate; 6(Z)-octadecenoic acid; 9(Z)-octadecenal and 7(Z),11(E)-hexadecadienal acetate; 1-isopropyl-4methyl-benzene; 4-isopropenyl-1-methylcyclohexil acetate and 3-pentadecylphenol, with chemical characteristics that generated strong antimicrobial potential ${ }^{14}$. The results of the current study showed, in low polarity fractions (ethyl acetate and acetone), the presence of phytochemical nuclei which may contain the compounds described by Urrea et al. ${ }^{14}$ and show the antimicrobial activity presented against the study microorganisms. Moreover, the ability of these compounds to provide protection to plants has been clearly demonstrated, thus, it is necessary to continue with the chemical characterization of the phytochemical nuclei in order to identify and characterize substances with potential antimicrobial activity.
The antimicrobial activity of $A$. excelsum found in the current study on reference ATTC strains of $S$. mutans, S. aureus, E. coli, E. faecalis and C. albicans, which are microorganisms which have been demonstrated to by highly pathogenic in different infectious processes of the oral cavity ${ }^{2,3}$, makes it clear that $A$. excelsum (Caracolí) leaves are a potential source of chemical compounds with antibacterial activity. It is thus necessary to conduct further studies to elucidate the action mechanism of these extracts and fractions, providing information on the content of secondary metabolites with antibacterial and antifungal activity, which -after evaluating pharmacological safetycould be used in the future as antimicrobial agents for infectious processes of the oral cavity.

To conclude, (1) the hydroalcoholic extract of $A$. excelsum leaves and the ethyl acetate and acetone fractions obtained from the hydroalcoholic extract at concentrations of 10 to $40 \mathrm{mg} / \mathrm{ml}$ had the greatest antimicrobial activity against $S$. mutans ATCC 25175, S. aureus ATCC 35548, E. coli ATCC 25922, E. faecalis ATCC 19433 and C. albicans ATCC 10231; and (2) the evaluation of the phytochemical nuclei in the ethyl acetate and acetone fractions showed compounds of phenolic type, triterpenetype terpenes and steroidal-type terpenes, which might explain the antimicrobial activity observed. 


\section{ACKNOWLEDGMENTS}

The authors thank the Herbarium of Universidad del Quindío (HUQ) for active collaboration with the Project, the School of Dentistry and the Office of the Vice-Rector of Science, Technology and Research of Universidad Antonio Nariño, Armenia (Quindío), and the Department of Microbiology (School of Science) and Center of Dental Research (School of Dentistry) of Pontificia Universidad Javeriana, Bogotá, D.C.

\section{DECLARATION OF CONFLICTING INTERESTS}

The authors declare no potential conflicts of interest regarding the research, authorship, and/or publication of this article

\section{FUNDING}

Research funding from the Office of the Vice-Rector of Science, Technology and Research of Universidad Antonio Nariño, Armenia (Quindío), and co-funding from the Department of Microbiology (School of Science) and Center for Dental Research (School of Dentistry) of Pontificia Universidad Javeriana, Bogotá, D.C.

\section{CORRESPONDENCE}

Dr. Fredy Gamboa

Departamento de Microbiología

Facultad de Ciencias, Pontificia Universidad Javeriana

Carrera 7 No. 40-62, Bogotá, Colombia

gamboa@javeriana.edu.co

\section{REFERENCES}

1. Ogle OE. Odontogenic Infections. Dent Clin North Am $2017 ; 61: 235-252$.

2. Arweiler NB, Netuschil L. The Oral Microbiota. Adv Exp Med Biol 2016; 902:45-60.

3. Li X, Kolltveit KM, Tronstad L, Olsen I. Systemic diseases caused by oral infection. Clin Microbiol Rev $2000 ; 13: 547$ 558.

4. Tent PA, Juncar RI, Onisor F, Bran S, Harangus A, Juncar M. The pathogenic microbial flora and its antibiotic susceptibility pattern in odontogenic infections. Drug Metab Rev 2019; 51:340-355.

5. Lemos JA, Palmer SR, Zeng L, Wen ZT, Kajfasz JK, Freires IA, Abranches J, Brady LJ. The Biology of Streptococcus mutans. Microbiol Spectr 2019;7:10.1128/microbiolspec. GPP3-0051-2018.

6. McCormack MG, Smith AJ, Akram AN, Jackson M, Robertson D, Edwards G. Staphylococcus aureus and the oral cavity: an overlooked source of carriage and infection? Am J Infect Control 2015 ; 43:35-37.

7. Walia IS, Borle RM, Mehendiratta D, Yadav AO. Microbiology and antibiotic sensitivity of head and neck space infections of odontogenic origin. J Maxillofac Oral Surg $2014 ; 13: 16-21$.

8. Ardizzoni A, Pericolini E, Paulone S, Orsi CF, Castagnoli A, Oliva I, Strozzi E, Blasi E. In vitro effects of commercial mouthwashes on several virulence traits of Candida albicans, Viridans streptococci and Enterococcus faecalis colonizing the oral cavity. PLoS One 2018 15; 13:e0207262.

9. Bertolini M, Dongari-Bagtzoglou A. The Relationship of Candida albicans with the Oral Bacterial Microbiome in Health and Disease. Adv Exp Med Biol 2019; 1197:69-78.

10. Rojas JJ, Ochoa VJ, Ocampo SA, Muñoz JF. Screening for antimicrobial activity of ten medicinal plants used in Colombian folkloric medicine: a possible alternative in the treatment of non-nosocomial infections. BMC Complement Altern Med 2006 ; 6:2.

11. Téllez N, Téllez M, Perdomo M, Alvarado A, Gamboa F. Anticariogenic activity of the active fraction from Isertia laevis against $S$. mutans and $S$. sobrinus: comparison of two extraction methods. Acta Odontol Latinoam 2010; 23:188195.

12. Aldana J, Tellez N, Gamboa F. Antimicrobial activity of fractions and subfractions of Elaeagia utilis against

microorganisms of importance in dental caries. Acta Odontol Latinoam 2013; 26:104-111.

13. Abouelhassan Y, Garrison AT, Yang H, Chávez-Riveros A, Burch GM, Huigens RW 3rd. Recent Progress in NaturalProduct-Inspired Programs Aimed To Address Antibiotic Resistance and Tolerance. J Med Chem 2019 ; 62:76187642.

14. Urrea-Victoria V, Sequeda-Castañeda L. Evaluation of extracts of Anacardium excelsum (Anacardiaceae) as alternative to the food preservation. Vitae 2012; 19:394396

15. de Araújo JSC, de Castilho ARF, Lira AB, Pereira AV, de Azevêdo TKB, de Brito Costa EMM, Pereira MDSV, et al. Antibacterial activity against cariogenic bacteria and cytotoxic and genotoxic potential of Anacardium occidentale L. and Anadenanthera macrocarpa (Benth.) Brenan extracts. Arch Oral Biol 2018 ; 85:113-119.

16. Dos Santos GHF, Amaral A, da Silva EB. Antibacterial activity of irradiated extracts of Anacardium occidentale L. on multiresistant strains of Staphylococcus aureus. Appl Radiat Isot. 2018; 140:327-332.

17. Barbosa-Filho VM, Waczuk EP, Leite NF, Menezes IR, da Costa JG, Lacerda SR, Adedara IA, Coutinho HD, et al. Phytocompounds and modulatory effects of Anacardium microcarpum (cajui) on antibiotic drugs used in clinical infections. Drug Des Devel Ther 2015 ; 9:5965-5972.

18. Celis C, García A, Sequeda G, Méndez G, Torrenegra R. Antimicrobial activity of extracts obtained from Anacardium excelsum againts some pathogenic microorganisms. Emir J Food Agric 2011; $23: 249-257$.

19. Dobner M, Schwaiger S, Jenewein I, Stuppner H. Antibacterial activity of Leontopodium alpinum (Edelweiss). J Ethnopharmacol 2003; 89:301-303.

20. Bauer AW, Kirby WM, Sherris JC, Turck M. Antibiotic susceptibility testing by a standardized single disk method. Am J Clin Pathol. 1966; 45:493-496.

21. Pinto D, Thomas A, Tabares T, Tenorio SF, Diaz C, BrazFilho R, Dacunha VL. Secondary metabolites isolated from Richardia brasiliensis (Rubiaceae). Braz J Pharmacol 2008; 18:367-372.

22. Sequeda-Castañeda LG, Muñoz-Realpe CC, CelisZambrano CA, Gutiérrez-Prieto SJ, Luengas-Caicedo PE, Gamboa F. Preliminary Phytochemical Analysis 
of Berberis goudotii Triana \& Planch. ex Wedd. (Berberidaceae) with Anticariogenic and Antiperiodontal Activities. Sci. Pharm. 2019, 87, 2; https://doi.org/10.3390/ scipharm87010002.

23. Gamboa F, Chaves M. Antimicrobial potential of extracts from Stevia rebaudiana leaves against bacteria of importance in dental caries. Acta Odontol Latinoam 2012; 25:171-175.
24. Kloucek P, Polesny Z, Svobodova B, Vlkova E, Kokoska L. Antibacterial screening of some Peruvian medicinal plants used in Calleria District. J Ethnopharmacol 2005; 99:309312.

25. Cowan MM. Plant products as antimicrobial agents. Clin Microbiol Rev 1999;12:564-582. 